\title{
Becoming Method(ologist): A feminist posthuman autoethnography of the becoming of a posthuman methodology
}

Katie Warfield, Department of Journalism and Communication Studies at Kwantlen Polytechnic University, Canada, e-mail katie.warfield@kpu.ca

\section{Abstract}

This paper contributes to the intersections of post qualitative methods, digital methods, and internet studies, by describing the becoming of a digital posthuman visual method. I use posthuman autoethnography to argue that in the production of this method, the "auto" or my academic selfhood is decentered and entangled amidst an assemblage of material, discursive, and affective forces such as neoliberalism, Trump era terror, and dataism. I introduce a multitude of data points typically not made to matter but through which these material, discursive and affective forces importantly flowed in this production of this method: emails, personal correspondences, restaurant conversations, self-reflection, conferences talks and responses to conference talks. I focus specifically on the moments where the values and principles of feminist posthumanism were jarred and destabilized or where I was made to choose between foregoing my values or redesign my method and myself as methodologist. I argue academics have a response-ability to show both the forces at play behind the becoming of qualitative methods and knowledge in academia.

Keywords: postqualitative methods, posthumanism, PhEmaterialism, social media 


\section{Becoming Method(ologist): A Feminist Posthuman Autoethnography of the Becoming of a Digital Visual Method}

In this paper I provide a feminist posthuman autoethnography of the becoming of a research method. This method, called Reading the Cuts, is a digital visual research method that explores the becoming of images that represent digital subjectivities shared on social media platforms like Instagram, Tumblr, and Snapchat. Sometimes we call these images selfies. Sometimes we call them self-portraits. Sometimes we call them auto-photography. Whatever the name, they are all images of momentary, fleeting, and changing selves that are taken with the aim to be shared online. This method was not of my making. To assume that anything is made in research by the magical solitude of the researcher is at once humanistic, selfish, and frankly delusional. This method became with and through the different cohorts of intersectionally diverse women I've worked with over the past five years: young cis-women, trans and gender non-conforming youth, queer women, and Muslim women. This method has come about through sharing at conferences and talks and rubbing it up against the brilliant minds of feminist colleagues via emails, skype calls, text messages, and intimate banter over teas and creamy coffees. It has come through early morning wake ups and laying on my side drooling and thinking about how to do what we do responsibly, ethically, and in a more just manner, and asking questions about the tools we use to do what we do. It has come about from difficult emotional moments. It has come about via tough decisions where, for instance, tossing out all the hours in a research program and starting anew was decided to be more ethical than "salvaging" crappy data so we could achieve our publication quota. This method would not be what it is without this assemblage of moments, their effects and impacts on the method, and their influences, impacts, and effects on both me and my research participants.

What is posthuman about this chapter? Everything. The posthuman, sometimes called new materialism (Barad, 2007), or the ontological or material turn (Haraway, 2016; Mol, 2003), refers to a shift in ontological orientations away from anthropocentrism (Braidotti, 2013), which privileges the human above other forms of life, and human agency above agency from the material. Instead, posthumanism recognizes agency of the non-human or more-than-human (Latour 1993). It marks a shift away from research methodologies that still hook talons into tendrils of positivist thinking (St. Pierre, 2014; Wolfe, 2010), and replaces the unified, static, bounded and unwavering human subject with decentered, nomadic, multiple, incomplete, complex, and tentacular (Harraway, 2017) becoming subject(s) in the plural. This chapter, then, is a posthuman autoethnography of how the method Reading the Cuts changed when I worked with a cohort of Muslim women in the Spring of 2018. The theoretical frame is posthuman, the method posthuman, the analysis posthuman, the choices made in the "data" and through its development are posthuman, and specifically feminist posthuman, which I will elaborate later. Since the posthuman turn is an ontological one, I argue it becomes increasingly difficult to adopt 
one posthuman element of a research assemblage without drawing in all elements into the beautiful movements, patterning, and flow that posthuman analyses beg of research inquiry.

This chapter begins by discussing what a feminist posthuman autoethnography looks like. Since the term autoethnography is premised on the humanist notion of the "self" - an "auto" upon which we can reflect and write-and posthumanism is premised on a decentered subject or the becoming of the subject, then the classic mode of autoethnography in qualitative inquiry looks significantly different from a posthuman perspective. Subjectivity looks particularly different when we look at digital phenomena, which are tangled amidst online and offline spaces, and visible and invisible sites and flows. Furthermore, researcher subjectivity becomes complex when looking at the becoming of a research method. The researcher evolves a method entangled among the micro-politics of the academic everyday (e.g. emails and daily encounters), through the situated politics of data collection, though macro-politics such as disciplinary logics and neoliberalism. I will show that the material machinery of novel qualitative methods is never distinct from the political of the situated everyday because the research method is never separate from the complex, decentered subjectivity of the methodologist. The method and methodologist become, or as Karen Barad (2007) would describe, intra-act, together. Methods are never fixed and neither are methodologists - both are always in process as "with each intraaction, the manifold of entangled relations is reconfigured" (Barad, 2007, p. 393-394).

In fact, the unit of analysis in the narratives below reflects this intra-acting entanglement: the data extracted from the endless potentials of data points in the becoming of the research method are the moments where the ethics enshrined in feminist posthumanism orientation (responsibility, justice, feminist ethics of care) were affectively jarred-such that they, in the moment, called for a reshaping of the research method itself. I am inspired by the term jarring from Emma Renold and Jessica Ringrose (2019), who elaborated a method of speculative "JARing" - actually using material glass jars to capture the creative thoughts of participants as $\mathrm{d}($ art)ifacts. It is their reference to the power of art to materially, discursively and affectively jar that I draw on in the data below. Jarring is process of "unsettling, destabilizing, vibrating, and jolting" (Renold and Ringrose, 2019, p.8). The data extracted below illuminates moments where the becoming of the research method(ologist) was jarred. However, given the posthuman decentered nature of researcher subjectivity, it was not always me that was jarred. Since I intraacted affectively, materially, and discursively with my participants, my institution, the various players helping me design this method, the materiality of the technologies of data recording, and the moments highlighted below are moments where the assemblage of the method(ologist) was jarred. Importantly, what happens in the moment of jarring is a redirection, a reorientation, and a reflection on the base values that drove the method and underscored this feminist posthuman project. The jarring sometimes resulted in redesign, it sometimes resulted in redirection, and it often resulted in reflection, pause, and recalibration. And so, below is a 
posthuman autoethnographic account of the jarring moments in the becoming of the research method(ologist) from 2015 to now.

To begin, I move from an overview of postqualitative methods through theories and recent posthumanist autoethnographic writings. I then move to reflect on a specific period of time in the "becoming of the research method of Reading the Cuts," a period in which I started working with a cohort of Muslim women on this method. I provide a posthuman narrative of the becoming of this method during that period. My aim here is not to focus on the details of the method and how it functions; rather, the aim is to focus on the becoming of the method and how the intra-actions with this particular cohort of participants importantly shaped the method via jarring moments of redirection and redesign. Throughout, drawing on material, discursive and affective flows that thread through different forms of media, different temporal timelines, and inside and outside voices, I weave a posthuman autoethnography that reveals the becoming of researcher subjectivities alongside the becoming of a digital visual posthuman method-in essence, the decentered, intra-acting, relational becoming of method and methodologist.

\section{Postqualitative Methods}

Postqualitative research methods begin with certain claims that are similar to posthumanism more broadly. For example, postqualitative methods reject the notion that "the human is the superior to and separate from the material" (Lather and St. Pierre, 2013, p. 630). The concern for materiality is, importantly, not a return to Marxist definitions of materiality. Instead it is "a return to materialism after Derrida" (Lather, 2016, p. 125), meaning that it is more interested in the intimate intersectional politics and effects on the body above discussions of base and superstructure explored by Marx. Postqualitative methods are also a move beyond phenomenological methods from interiorized and individualized experiences - which reinforce a humanist conception of the unified subject-to "a materialist, relational, co-constituted, affective, vitalist, corporeal notion of experience" (Taylor, 2017, p. 313).

\section{Post "Auto" in Autoethnography}

Postqualitative research challenges humanist conceptions of the bounded, unified, singular subject. Postqualitative research traces the notion of subjectivity from the "the unified, conscious, and rational subject of humanism through the post-unionist, desiring subject to the Deleuzian subject" (Lather, 2016, p.125). As Rosi Braidotti (2013) theorizes, the post-post subject is more about foldings than layering and splittings (p. 20). For Patti Lather (2018, p. 345) this complex subject is the "incalculable subject" - the subject that is always in the process of changing and becoming and so can never be fully known in any given instance. In a political vein, this subject also runs contrary to "neoliberal and big data efforts to count and parse, 
capture, and model our everyday moves, a subject outside the parameters of the algorithms" (Lather, 2016, p. 126). This notion of subjectivity also aligns with the previous comments on the erasure of the textual/material divide. The subject is a collective of utterances that formulate and shape the body, as MacLure states:

Utterances do not come from 'inside' an already constituted seeking subject. Language, already collective, social and interpersonal, pre-exists 'us', and my voice comes from elsewhere (MacLure, 2013, p. 660).

Subjectivity is not a singular bounded, fixed, and static phenomenon, but rather, it is always a threading and knotting of historical and imagined future material-discursive entanglements.

This rethinking of subjectivity also forces a rethinking of the researcher's subjectivity, and not simply that of the participants in the research. The presumed positivist assumptions underlying classic qualitative methods are premised on essentialism which "imposes itself on qualitative methodology by assuming people (authentic, stable subjects of research), speak (from a curious center) and give us (the researcher, also authentic), rational, coherent truths that serve as the foundation (data) for data analysis and interpretation" (Jackson, 2013, p. 742). When both the researcher and participants are recast as assemblages in motion-entanglements of becoming resulting from past collective material-discursive forces-notions such as voice, data, and classic processes of analysis must also be rethought as being more complex, more layered, unbounded, and always shifting.

When the subject is decentered, multiple, nomadic, and changing, when agency is spread along material, discursive, and affective tendrils, then what constitutes data, what comprises "voice", and the linear and bounded first person structure of an autoethnography all become complicated - they all must be rethought in a posthumanist manner that aligns with a posthumanist ontology. The first-person voice of the self may become multiple, fragmented, or incomplete and in motion - that is, uncertain. It may slip backward in time to former situated and knotted moments of subjectivities where different material, discursive and affective forces flowed. It may reflect on research reflexivity in a posthuman manner, incorporating thoughts on the forces of production of the text itself-a sort of posthuman cracking of the $4^{\text {th }}$ wall as the text itself comes to reveal its own becoming (Lenz Taguchi, 2012; Warfield, 2018).

Further, since agency emerges no longer from the singular self, then space must be made for other "things" to speak: vital matter (Bennett, 2010), what we may call objects, spaces, multiple media broadly (the materiality of discourses), like scripts but also mass media, songs, poetry, visual and performance art, memories (Fox, 2016), diaries and memoirs, bodies and body parts (Raun, 2016), technologies (Warfield, 2018), text messages, social media posts, online forum 
postings, and all sorts of ways that feelings (Kuntz and Presnell, 2012) entangle with, through, and in relation with these material and discursive assemblages.

\section{Posthuman Autoethnography}

Several scholars have written explicit posthuman autoethnographies, and others have written autoethnograpies that align clearly with the format and underlying principles of posthuman autoethnographies. Ken Gale and Jonathan Wyatt present a political argument for a posthuman approach to autoethnography, arguing that autoethnography continues to "locate itself within the subject-centered proclivities of humanist thought and phenomenological inquiry" (Gale and Wyatt, 2018, p. 1) and to resist a metaphysics that includes affect, materiality and the posthuman. They argue that if autoethnography is activist to any degree, it is unjust and perhaps immoral to not consider the nonhuman along with the human in relationality:

"It is not enough to talk about the work that is done by bodies that are simply human. (...) Therefore, an activist autoethnography must come to terms with the rhetoric of Spinoza that says that all bodies, human and nonhuman, have the capacity to affect and be affected: Autoethnography, activism, and power cannot be understood outside of the micropolitics of this" (Gale and Wyatt, 2018, p.1).

Katie Strom et al (2018) argue, in the introduction of a book on intimate posthuman scholarship, various case studies that adhere to postqualitative ontologies and re-examine what intimacy means in the production of data. They argue that whereas intimate classic qualitative inquiry like autoethnography attends to a humanistic orientation to the research subject, in posthuman intimate scholarship "the emphasis must be on looking outward, not inward" (Strom et al 2018, p. 6). For instance, Jordan Corson and Tara Schwitzman (2018) blur the delineation between autoethnography and literature review to reveal the way in which theory attends to our being and becoming and becomes anchored to us because of our relational experiences. As another example, Chau Vu examines the concepts of objectivity and reliability in research and instead proposes a form of diffractive autoethnography which "shifts its focus from to tell to to know while being, and accordingly, the autoethnographer is expected to part with what s/he think s/he knows, confront her/is privilege and authority in listening and telling, to fully come to her/is own presence" (Chau, 2018, p. 86).

\section{Doing Posthuman Autoethnographies}

How do we do posthuman autoethnographies? Different authors have adopted different creative tactics. Gale and Wyatt suggest that methods of posthuman autoethnography should be "less reflective, less personalized, less human/centric and more relational, more 
non/human/centric and more engaged with the entanglements of materiality and discourse that enact the inevitability of lives" (Gale and Wyatt, 2018, p. 3). Anne Harris, a foundational scholar in critical autoethnography, has recently contributed writings that align with a posthuman ontology. Their piece "Monument" toggles between different voices, querying the author, replaying temporality, and incorporating matter/what matters. They move from structure to the structuring of discourse. They incorporate modes of media from dictionary definitions to dreams, trails of thought, rhizomatic ideas in media and over time.

As another illustration, Summer Dickinson (2017) contemplates the affective-materiality of an Oreo cookie in her piece "Writing Sensation", using the first-person voice to continually come back to the cookie as an object of vulnerable decentering of the researcher subjectivity, "arguing that objects can become the thing that challenges us to explain the assemblages of life" (p. 86). To discuss the gendered norms associated with parental care work, Genine A. Hook and Melissa Joy Wolfe (2017, p. 1066) write of a sort of posthuman personal recounting as productive situatedness, which we utilize as a "processual becoming in which things do not exist but come into existence with the material relations in which they are." They adopt a diffractive analysis to re-think a phenomenon, recognizing that the rethinking in fact changes the thing being thought. They also adopt creative writing tactics like "rewordings signifying motion and change: re/productive, re(con) figuring and re/normalization highlight[ing] the connectivity of the world" (Hook and Wolfe, p. 1068). Finally, Corson and Tara Schwitzman (2018) adopt a co-written unified voice and creative methods like humor and satirical voices in footnotes to make visible the literal "spaces" in academic writing, journal article structures, in which certain affects, experiences, and voices are permitted to enact and be, and in which other voices, tones, and affects are excluded.

\section{Approaching my Posthuman Autoethnography}

If subjectivity is fundamentally decentered in posthuman methods, and posthuman autoethnography focuses on the becoming of phenomena, then this autoethnography below narrates specific moments in the relational becoming of the researcher and the research method. In the next section, I adopt various tactics from posthuman autoethnography to recount the material-discursive and affective encounters that created a jarring effect on the method(ologist). As mentioned earlier, I purposefully complicate the presumed divide between researcher and research method, arguing them to be relational, co-constitutive, and entangled. A posthuman orientation towards researcher subjectivity sees subjectivity as entangled amidst the material, discursive, and affective complexities of its nomadic situatedness, and so the researcher subjectivity relationally becomes amidst a myriad of moving parts: the subjectivities of the research participants, the evolving research method, the machinery of the institution in which she works, the disciplinary logics within which she stews, and the technological 
apparatuses she adopts and adapts for data collection. Amidst all these moving parts, however, I kept one thing fixed, my adherence to the values that underscore feminist posthumanism: response-ability, justice, and feminist ethics of care. As a result, when I pick the jarring moments in the narrative of the becoming of the method(ologist), I am choosing moments when my adherence to those values was shaken, disrupted, unsettled, and challenged. This unsettling was caused by a "derailment" from the original underlaying values and principles of feminist posthumanism. When the method(ologist) was jarred this caused a moment of troubling (Haraway, 2016), where I found myself choosing between foregoing my values or adapting my method and myself as methodologist. This process involved reflecting on myself in a posthuman manner-not as a singular subject but as produced by various material, discursive and affective forces within academia, as well as facing recognition that I may also be reproducing them. I also projected forward in imagining the implications of the design of my method not only for my present cohort of participants but also for the future cohorts who may use this method for data collection and the production of knowledge. I saw myself as method and methodologist, recognizing my response-ability to the material design of the tool. It is in examining these jarring moments in research that we can see the manifold forces that came into play in the "agential cutting" (Barad, 2007) involved in the design and redesign of the research method. Again, the aim of this narrative is not to detail the methodology of Reading the Cuts; rather, it is a narrative that can be used by other researchers to reorient our approach to methods, to reorient our assumption that methods are separate from methodologist, and to deeply highlight the way in which values and principles permeate not only what we do as researchers but the tools that we produce for research. Importantly, the cuts we make in those jarring moments reflect the moments in which we make our methods and ourselves as ethical and responsible (or not) researchers.

Through this narrative I also play with a decentered subjectivity and voice, temporal lines of flight from past to deep past to imagined futures. I integrate different locations, space, and media in the retelling of the mangle of practice (Pickering, 1996) that yielded changes in the pedagogical-methodology as it presently stands. Importantly, I flow between scales and flows of power from macro-political contexts (e.g., the Trump era and neo-liberalisation of academia), to micro-scales of self-reflection and research doubt, to reveal that material, discursive, and affective flows pierce and flow equally at all scales of qualitative inquiry and thread into the mechanics of the research methods we develop and use in knowledge creation.

\section{Posthuman Narrative}

In this next section I draw on a series of these jarring moments to show the shaping and reshaping of the method and methodologist. For clarity I often adopt the position of "I" but I also play with it, dropping it, moving other figures into the central role as narrator, and 
sometimes allowing non-human actors to speak and play a role. I label each snippet of data to sign post the move through time, space and media. In the end it is the entangled material, discursive and affective intra-acting moments that I wish to make speak to show how a posthuman autoethnography can reveal through narrative the complex ways a research method becomes in academia. I provide overarching headings for three jarring moments and the steps and struggles that led up to and emerged from them: 1) affective jarrings, 2) technological jarrings, and 3 ) discursive jarrings and rethinking. At the end of each of these three sections, I add a paragraph of reflection that offers a brief analysis of each moment and the becomings that were enabled by various intra-actions.

\section{Affective Jarrings: Trump in our Mi(d)st}

\section{Excerpt from Diary entry Nov $8^{\text {th }}, 2016$.}

What a tough day. I think I'm still in denial. It's like a terrible bad dream or some sort of joke. In class today there was definitely an air of fear. I felt students weren't really engaged. Instead we decided to have a bit of a discussion about it. Lots of people admitted their fears. Lots of the South Asian students said it made them scared, not so much about the US broadly, but about how this will impact THEM on the daily. One guy said that ever since Trump's been on the docket he's felt a little more uneasy in Surrey. He said it's like Trump's overtly racist comments have made it seem like it gives certain kinds of white people the right to be more racist in their everyday lives. It was so draining. We tried to discuss what we could do in the classroom moving forward. I'll have to think about this. One student wrote a reflection card that gives me some hope, helped me stay positive. It said: "It feels like a dark time but sometimes it's in the dark time we have to remain the strongest. I will strive to see the light."

\section{$* * *$}

Personal Email, Nov 2018

From: Office of the Dean of Arts: CFP FAEAF Internal Grant

To: Arts Distribution List

Dear Faculty, 
The Faculty of Arts Excellence and Advancement Funds are intended to support a range of projects and partnerships that further the Faculty of Arts' commitments to teaching excellence, research, scholarship...

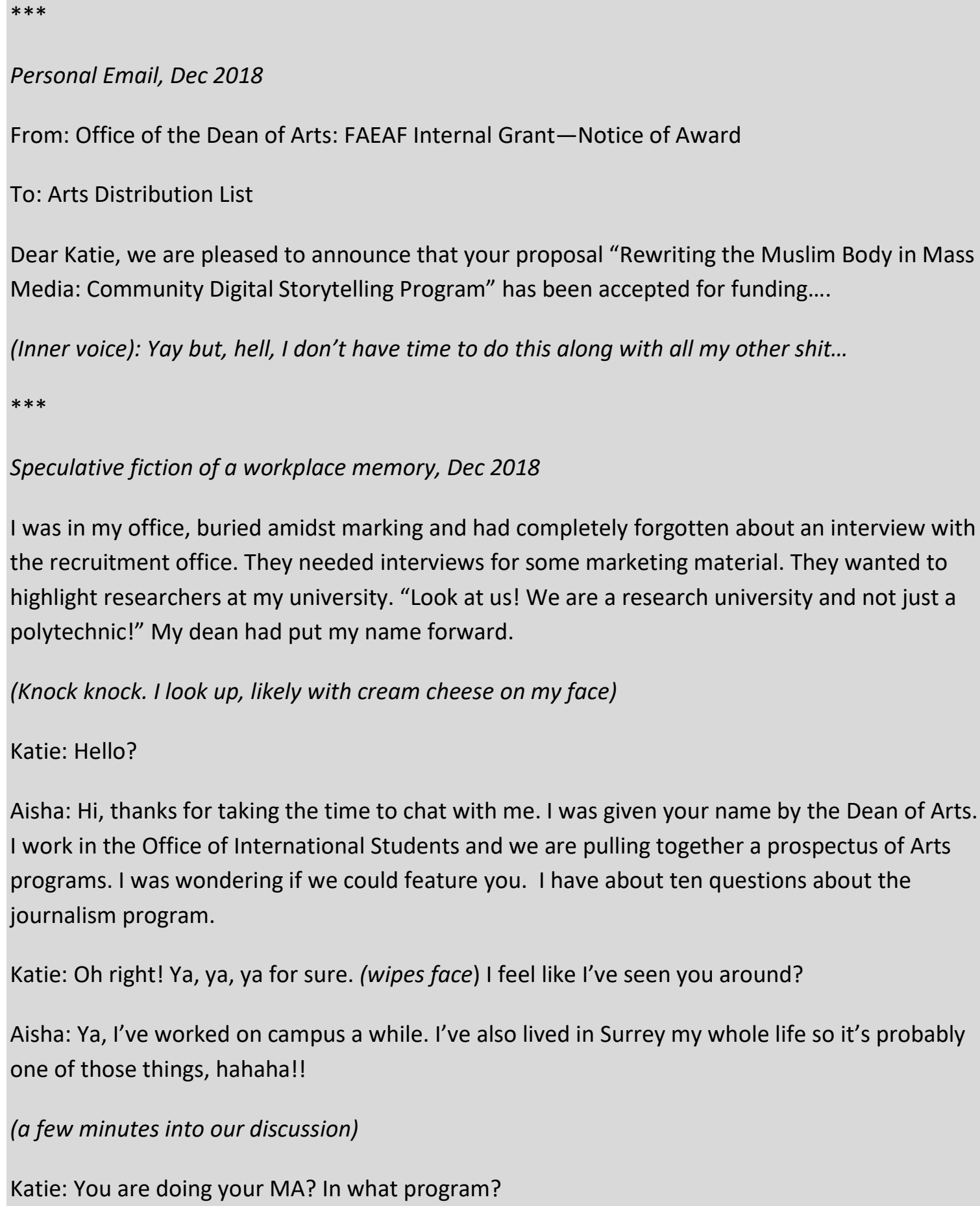

Aisha: $\mathrm{Hi}$, thanks for taking the time to chat with me. I was given your name by the Dean of Arts. I work in the Office of International Students and we are pulling together a prospectus of Arts programs. I was wondering if we could feature you. I have about ten questions about the journalism program.

Katie: Oh right! Ya, ya, ya for sure. (wipes face) I feel like I've seen you around?

Aisha: Ya, I've worked on campus a while. I've also lived in Surrey my whole life so it's probably one of those things, hahaha!!

(a few minutes into our discussion)

Katie: You are doing your MA? In what program? 


\begin{abstract}
Aisha: Education at SFU. With a focus on social justice. I'm interested in media representation. Growing up in Surrey I always hated the way we were represented-it was either gang fights or intergenerational conflict. I don't like how youth in Surrey are represented in media. I'd love to eventually do my PhD and work toward changed the representation of Muslim people in media broadly...

Katie: How heavy is your workload this coming semester?

\section{$* * *$}

Aisha had run the DigitaLENS community storytelling program for the first two semesters. I had sat in on several workshops but it was hard to be present with all my other work. Aisha and I had met at the end of the second term to debrief. We had exhausted funding but Aisha said we really needed to keep the program going. She handed me a pile of testimonials from students. I read them and I started to weep.

Excerpts from testimonials included in KPU internal Katalyst Grant, Spring 2017
\end{abstract}

\title{
Testimonial 1
}

"To say the Voices of Muslim Women Digital Storytelling Program is unique would not be giving it the justice it deserves, for it is so much more than that. Part social justice learning, part collective therapy session, part film making and photography skill building - it comes together to form a twice weekly class that asks students to think, think again, examine, self reflect and finally to create. Surrounded by a diverse group of other Muslim women, I felt safe to share and express and to listen and be heard. The space created allowed me to dive into my memories and feelings, I was able to produce a five minute film about my life journey. Creating this piece of work was something I would not have done if it was not made possible by this class. This is monumental because it was the soft stepping stone I needed to remember part of me that I thought was lost. Experiencing my classmates create their digital stories was a learning as much as it was an inspiration. Each class enabled us to find out a little more about the other culminating in a group of women that have become true friends. And it is in that I believe the ultimate value in this program lies. It's the connection and the collective knowing that we are not alone. It's being seen and realizing that our voices are heard. And then ultimately it's the taking of those voices out of the classroom and into the community to raise awareness, create change and enable women to stand up and speak up in ways they may not previously have thought possible."

Testimonial 2 


\begin{abstract}
"I was wary about taking the program but I'm thankful I did. The instructors taught me what it means to be an advocate for social justice, that the process of taking a selfie reveals who you are and how to create a digital story. I'd recommend others to take the program, not only because of what you'll learn, but also because it gives you a sense of safety to openly share your stories and form friendships that will last a lifetime."

Testimonial 3

"The VMW Digital Storytelling course was the space that I needed to meet Muslim women in my community and find safety to share my story. Beyond teaching us the craft of story building, selfie making and digital storytelling, what set this course apart was the space that was held for us every week to share unapologetically. Aisha, Katie and Alia created a class that cultivated our stories in a way that remained true to ourselves."

$* * *$
\end{abstract}

\title{
Personal Reflection on Response-ability and Affective Jarrings written in fall of 2019, but reflecting on 2017
}

Until this point, we had been playing with different pedagogies for discussing self and selfimaging practices. I had thought about the methods we were developing becoming an actual method, but I just couldn't let myself think too hard about it. I didn't have the time. Between teaching four courses, marking papers, and writing grants, I had to pick and choose what was important. I felt like I wasn't spending enough time with my kids. I wasn't taking time for myself. When I read the program testimonials, my feelings were conflicted: I felt rage, because I was doing too much, and sadness. The testimonials made me realize the importance of this program for the participants. We had created not only a space of crafting, but a space of becoming-a safe space to share feelings that were difficult to share elsewhere, a program that allowed some women to grow and heal. My rage came from a voice in me: WHY DO I HAVE TO DO EVERYTHING?? MAKE THE LUNCHES! WRITE THE GRANTS! RUN THE PROGRAMS! TEACH THE COURSES! MARK THE ASSIGNMENTS! I was envious of friends are at research universities with teaching assistants and abundant funding and only two courses to teach per semester instead of four. I breathed and the sadness flowed in. What a selfish way of being in the world. In response, I drew on posthumanism as almost a form of therapy. How would Karen Barad reframe what I was feeling and thinking? I was pitying myself, a white, able-bodied, privileged, successful, and financially-secure academic. Cry me a river. I could choose to see myself as a solitary and singular subject responsible for everything, or I could reframe my subjectivity in a posthuman manner. I am an assemblage of people, privilege, opportunities, and provisions. I am who I am because of these women, this institution, this local community. These testimonials 
were thanks and gratitude. My privilege demanded of me response-ability, and it was that moment that the sadness evolved into feeling of deep conviction. The self-pity turned into deep responsibility, the jarring and reframing of myself as not singular, but as an assemblage intraacting among various forces networked among systems of privilege that enabled this sort of program to exist. Testimonials were these thanks to me. Continuing the program going was going to be my thanks to them. This reorientation towards seeing myself as a posthuman assemblage and not a singular subject erased any voice in me that said doing this work was too much. It was this jarring emotional moment that fuelled my conviction for responsibility, justice, and care.

Speculative fiction family memory, Fall 2017

E: Mummy, what is this glass thing for?

Me: It's an award, lovey.

E: For what?

Me: It says Allies of Muslim Women Award, Voices of Muslim Women Gala, 2017.

E: I really like it.

Me: Me too.

\section{Technological Jarrings: Politics of Seeing and Being Seen}

Almost two years in and I could hardly believe it. Our videos had circulated online and gone viral. Aisha had met with people from the City of Vancouver, provincial representations in the education department. She'd even had lunch with a few people who had reached out from the UN Entity for Gender Equality. This program was not going to disappear.

Excerpt from Conference Presentation Talk, PhEmaterialism Conference 2018

London, UK

Jet lagged inner voice: Just happened across the Royal couple leaving some royal building in a horse drawn carriage. God royalty is weird.

"Three years after I began working with Voices of Muslim women I asked if I could use my novel digital visual methodology Reading the cuts with them. I had been using it with different groups 
and I thought it would make for an interesting class exercise. The cohort was studying photography and digital storytelling. I needed a way to study the becoming of the photo without being "in the room" for the photo taking. I needed to "be there" as best I could-to be proximate and close to the phenomenon-but I also needed to not be present so that I didn't influence the production of the phenomenon. Self-portraiture is a really private thing. People don't like taking photos of themselves if someone else is in the room. How could I achieve this?"

Excerpt from personal email correspondence with my friend, a computer programmer and mega nerd. Spring 2017

Dear Mitch, I know you are super busy with work but I wanted to ask if you know how hard it would be to design an app that can screen record in the background while a user uses another app like Instagram or something. No rush on this. Let me know if you have a sec.

(one week passes)

Hey Katie!

This is an interesting question! What are you using it for? Sound very similar to user experience apps that we developers use to study how users use their app and then to tweak the design based on things like common hang ups, or whatever-we basically use it to make the interface better. I don't see why you couldn't use one of those to record people taking images of themselves. I found this one online. www.lookback.com/ Looks pretty intuitive.

Mitch.

Excerpt from Conference Talk, PhEmaterialism Conference 2018 (yes, same talk as before)

London, UK

\section{(5 minutes into talk)}

"My original plan was to hijack the use of a user experience app in order to record in the back ground, the process young people took in the production of a selfie or digital self-image. User interface apps are designed to run in the background of any app and screen capture anything a 
user is doing. They permit user interface designers to see movement, pause, troubles, and design glitches in order to design a better user interface. I was using it to watch the user in the process of producing self-images. I held a workshop in which we downloaded the apps to phones and played around with the app until participants felt comfortable. I did a few trial runs of image capture with them in which I provided them with a series of self-directed discussion question, and then sent them on their way for a week of field note collection. We'd meet individually after the week and go over the videos.

Now this was the original plan. What l'd like to discuss now, however, were the material, discursive and affective troubles of introducing this method, and then describe the Reading the Cuts (redux), version 2 we are currently working with.

Several troubles emerged in the testing and planning phase of this method. The app we originally were planning to use, called Lookback, is downloaded to the phone, turned on, and runs in the background of the phone until the user turns it off. The app was developed originally for IPhones in 2016 and just this past year for Android. Whereas the Apple version seemed to work smoothly, the android version, however, had many glitches, in particular when you turn the phone from one orientation to the other, the audio would work, but the visual would stick in the original orientation used and the visual field would turn macro and all you would end up seeing was a talking eyeball or ear."

$* * *$

Transcription of video from data collection Fall 2017/Spring 2018

Participant 1 (age, 55): Works on my phone!

Participant 2 (age 18): Doesn't work on mine. What type of phone do you have?

Participant 1: (age, 55): The new IPhone.

Participant 2: Oh miss fancy pants! That's probably why.

$* * *$

Excerpt from Conference Talk, PhEmaterialism Conference 2018 (yes, same talk as before)

London, UK

"The politics of Apple vs Android apps, the dominance of Apple in the realm of apps and the class divide between Iphones (retail \$990 CAD) and androids (phones in the range of 0-100\$ on phone plans) were a major consideration for us. Using this app would mean only Iphone users 
would be able to collect clear visual data which means we would be limiting our population to only Iphone users if we wanted the visual data. This also meant we would be bowing to the techno-politico-capitalist-logics of the cellphone industry and inviting only participants of a specific socio-economic class to our population. We looked at and tested out another 8 user experience interface apps and ALL of them had the same glitch-issues functioning well with Apple and glitchy on Android phones.

A feminist materialist ethics of care takes a response-able approach to the safeguarding the welfare of participants (Warfield, 2018 ${ }^{1}$ ). Importantly too I define the participants themselves not in a humanistic way whose subjectivity might end at the material edges of the skin, but instead I define the participants themselves as posthuman assemblages whose subjectivities stretch tentacularly out via data doubles (Haggerty and Erikson, 2003) to manifold online spaces. Thus the ethics of care in developing a posthuman digital visual method safeguards the welfare of the fleshy-body of the participant in the here and now but also the digital affective and material tendrils/tentacles that extend into online spaces in the here and now and more long term since images of bodies online often have a longer shelf life than offline expressions and self-presentations.

Any of the glitchy apps were appealing because they stored the video data directly on the phone. This helped in terms of data security as the data wasn't networked and stored off the device. BUT most participants did not have large storage on their phone (again, because this is costly, and thus another socio-economic consideration). This meant using these apps would limit the amount of video they could take for their field diaries. The appeal to Lookback was that data was stored in cloud storage which meant the issue of on-phone data storage was dealt with. Orienting myself to feminist material ethics of care, and seeking to safeguard the tentacular data doubles online, though, I had to ask "where is this cloud?"

$* * *$

Transcription from Live Chat with robot (or real?) customer service representative Johnathan ${ }^{2}$ from Lookback, Spring 2018

Katie: Where is the data stored after it's captured? On the device or elsewhere?

Johnathan (go-to Lookback customer service consultant. Possibly a robot): Hi Katie! Thanks for your question. The data is stored in servers in Ireland.

1 Uhg I hate citing my own research in my own research. But my mentor said "leave it in!" because citations are gold.

2 Johnathan is a pseudonym for the actual person I corresponded with at Lookback. 
Katie: Thanks, Johnathan

$* * *$

Field notes after Live Chat above:

After this discussion I started googling and taking notes about data privacy laws in Ireland. All looked good. I decided to go for it.

Email excerpt from real or robot Johnathan, Spring 2018

(1 week after Live Chat session)

To: Katie

Hi Katie, just a follow up to our conversation last week about data storage. Yes our data is stored in servers in Ireland but before it reaches there it is stored momentarily in the US...

$* * *$

Excerpt from focus group, Spring 2018

Katie: So let's read through the consent form. It's sort of a pain but important to do before we do research together.

(...)

Your data will be stored in Ireland but will be temporarily stored on servers the US.

Participant 1: Will they be able to look at my data whenever they want?

Participant 2: I don't like the idea of my photos being stored in the US.

Katie: Well...

Participant 3: Trump hates Muslims.

Participant 5: What's the point of confidentiality if they can just take what they want?"

$* * *$

Excerpt from Conference Talk, PhEmaterialism Conference 2018 (you know the one) 
"The discursive construction of the Trump-era US as a racist, surveillant, panoptic state with an aggressive disregard of privacy affectively and discursively permeated through and into the material app I'd planned to use. I had developed a good working relationship with my participants. I cared for them, but I also needed to care for the extensions of their networked affective data doubles onto networked spaces in my research. Apart from the technological glitches, the geo-political-material-affective glitches also made me rethink the appropriateness and invasiveness of the method I was proposing.

The surveillant/panoptic influence manifested in other ways too. When we held the workshop, the participants commented on the 'ickiness' of how the app ran in the background of other apps. I thought it was beneficial that I had found a way to remove or at least obscure and make less visible the recording technology. In practice though, the partial invisibility/partial visibility of the recording app also had an affective impact. Whereas typical reactions to visible recording devices are "discomfort and embarrassment", the affective responses to the invisible tool were articulated as being 'icky' 'creepy' and 'weird'. 'I know it's there, but I can't see it, which almost makes it worse, you know?' said one participant.

Rather than writing out their reflections on the self-imaging assignment I thought students could speak directly to the camera and record their thoughts saving them time. This too seemed to have an unexpected affective reaction. One participant said 'I talk to my phone to talk to people not to talk to myself'. Another subject said 'It's weird I'm talking to myself about watching myself, watch myself HAHAHA'. What I thought would be a novel and innovative technologically enabled qualitative method was met with a lot of scepticism and discomfort. My participants were not a fan of my non-human invisible interviewer.

\section{Personal Reflection on Technological Jarrings and Response-ability, written in fall of 2019, but reflecting on spring and summer 2018}

This was the compilation leading up to my second jarring moment. The technologies I wanted to use for this data collection were rubbing up against me and my participants in too many uncomfortable ways. The data storage made people too uncomfortable and my adherence to feminist ethics of care rooted in feminist new materialism did not allow me to just overlook the treatment of my participants bodies and data doubles. Furthermore, my participants felt the technology of data recording was too creepy-a sort of invasion of privacy. The apps available were also socio-economically exclusive, permitting people with more money for better phones or with more memory to use the apps that worked well. My adherence to principles of inclusion enshrined in PhEmaterialism meant that I could not choose to exclude membership based on class. In short, the method was not going to work the way I had planned. Amidst this jarring confrontation with these various technologies, and reflecting on my ethics of care, the method 
as it currently stood would not do. It was either my values or a new method. Or maybe it was both? In rooting down my values, allowing myself more conviction in my values as a researcher, it demanded a new method. The methodologist-filled with a stronger sense of justice-was rejuvenated, and the method had to be redesigned. Back to the drawing board, I decided. Back to the drawing board.

\section{Discursive Jarring: Article as Mentor}

\section{Excerpt from Conference Talk, PhEmaterialism Conference 2018 (you know the one)}

"As one does when things in research fail ${ }^{3}$, I sat with the trouble, sought a moment of deep reflection had a minor existential crisis and deeply paused on what I was really trying to accomplish with this method. I was inspired to return to the writings of autophotography theorists from the analogue era of the 1990's. Had I read everything? Did I need to reinvent the wheel? In a Deleuzian way, I returned to the broad cartography to reread those original articles from the mid 90's when autophotography was a popular method in psychology and ethnography. It was as if I needed some paper-based scholarly mentorship to work through my troubles. It only took one article, by Butz and Cook (2017), to help me realign with my goals and values. Here was my scholarly guidance. With deep humility the authors spoke about their assumption that the researcher had to be present in the moment of data collection. They retold the story of how a team of researchers had been trained to follow a group of nomadic mountain tribes through the paths they took from home to village. The recording team trundled along behind these participants lugging cameras and writing equipment desperate to capture the nomadic participants 'in the moment'. They recorded for months and then realized that since the start of the data recording the participants had been altering their routes home. They had been altering the routes in order to make the trails easier for the data collectors and all their heavy equipment. I reflected on Barad and her description of Heisenberg's uncertainty principle: you can't even know the location and the speed of an atom at the same time because the tools of measurement literally relocate the atom. The apparatus of data collection in fact alter the very nature of the data under study. What a humble face slap. Why did I feel I had to be present? Why did I feel I need to 'see' the experience of self-imaging? Why didn't I trust the participants could provide and record that themselves?

${ }^{3}$ Was it a "fail?" Reword? 
In this moment of reflection, I realized that I was being influenced by certain ideologies that permeated the disciplinary logics I was drawing upon in my method: dataism in social media theory and the shininess potential of novel postqualitative methods.

(INSERT SLIDE on Dataism. Photo of zeros and ones? Something typically "techy")

Jose Van Dyck (2014) argues that in the age of social media and big data collection, dataism has emerged as 1) a social media logic and secular belief system based in the naïve entrusting of our data to the connected ecology of corporations, and other public institutions likes academic research and law enforcement. Second, dataism reifies deep and detailed data as the paradigmatic form of empirical facts. It is a form of neo-positivism that presumes that the closer we as researchers can get to the granular quantified activities of our participants, the more information we can collect, the more valid and true our data. I was presuming that the closer I, as researcher, could get to the moment of digital self-production via images the more real would be my data. In line with dataism, I was also favouring MY ability as a qualified researcher to collect that data instead of the participants being involved more actively in the data collection process themselves. I had to ask, as Erin Manning does, could I "imagine not being the master of [my own] acts" ? ${ }^{4}$ Arguing from a feminist and postcolonial standpoint, Butz and Cook (2017) call for attention to epistemic injustices, which occur when a participant "is wronged in their capacity as a giver of knowledge" or "wronged in their capacity as a subject of social understanding or as a knowledgeable speaker". In ascribing to the principles of dataism by emphasizing the importance of technologies in data recording, I was performing a mode of epistemic injustice by not permitting the participants to narrate the becoming of their images.

\section{(POWERPOINT SLIDE WITH PICTURE OF CROW AND SHINY THING)}

I am really interested in developing and rethinking qualitative methods within a posthumanist frame. I've remixed several other methods for studying social media phenomena. I love the creative work of Elizabeth Adams St. Pierre $(2014,2017)$. That said, amidst the excitement of shiny new methods, not every method needs to be tossed. What needs to be achieved alongside the "need for new methods" is critical inquiry into "what methods do and will do". An inquiry into the ethical outcomes of new methods.

I couldn't just reify the ontology of new materialism and the tools of new technology, I had to ask, as Spinoza via Nick Fox asks, "what ethics enhance capacities for action?". However, I'd also add: and the capacities of WHOM for what action? My method enabled me certain capacities. They permitted me to challenge established qualitative methods and perhaps other researchers

${ }^{4}$ Who cited her? I'm not sure. I was still jet lagged. 
too if the method was taken up. They had the potential to enable me the capacity for social capital if the method was taken up. But none of these capacities were really productive for the capacities of my participants. In fact, in some instances Reading the Cuts seemed to reduce the capacities of participants: it reduced capacities to potentially control their data and it reduced their capacities to feel safe in terms of their data storage. Could I reimagine the method so that it was the participants who were experiencing increased capacities for action? Reflecting and realigning, could I reimagine this method along the real underlying values of feminist new materialism?

My new method aimed to deal with the material, discursive, and affective troubles of the former method. My new method is much more simple. I decided that what we would do is have similar workshops with participants, but instead of training students in technologies, I would simply train them in the interview questions of the method itself-the questions I would have typically asked of them. They would be their own auto-photographers and auto-ethnographers. They would take the photos. They had the option to write, audio-, or video-record the responses to their questions that helped to tease out the various material, discursive, and affective forces. In trusting the participants, and working against epistemological injustices, I worked against dataism and believed I no longer had to be proximately present for them to do the research. I trusted them and they too felt trusted by me. I call them my researcher/participants and tell them they are researching themselves. The participants since have done incredible work on their projects. Two of the participants have told me that they have been inspired to potentially think about grad school. Now that data collection is over, l've invited a handful of the participants to join me on some of my fall empirical data collection as a form of response-able mentorship so that they can receive the scholarly publication credentials and thus social capital that would serve them well in their applications to grad school."

\section{Personal Reflection on Discursive Jarrings and Response-ability, written in fall of 2019, but reflecting on 2018}

Reflecting on and realigning my values with those of PhEmaterialism - response-ability, social justice and ethics of care-meant that my method had to be adapted away from the influences and pressures of disciplinary logics that said I had to be present in the moment of data collection rather than choosing trust and participant empowerment. This new method allowed participants the comfort of collecting their own data. Thus, in this moment, I realigned my values away from disciplinary logics and towards, again, feminist ethics of care. At the same time, the method was also redesigned. The redesign permitted my participants to feel less "jarred" by the technologies of data collection we faced earlier. It allowed participants to experience what it's like to be a researcher of themselves, and it also allowed them the opportunity to-in the role of research-possibly be involved in further research and publishing 
opportunities, thus working against the hierarchy of researcher over participant. Overall the method and methodologist again intra-acted together to become anew through a moment of jarring.

$* * *$

\section{Non-Conclusions: Feminist Posthuman and Material Researcher Jarrings} and Becomings

In this chapter I provide a posthuman autoethnography of the becoming of the Reading the Cuts method-I particularly narrate how it evolved working with a cohort of Muslim women over a period of three years, but I do so while also situating our relationship within its much longer entangled history with the local community of my university, my classroom space in a postTrump era, the internal funding available to me, and the lack of resources common in neoliberal universities to do everything expected of university faculty members. My aim is to show that the becoming of the method was entangled amidst the micro-politics of everyday academia, the mezzo-politics that emerge in empirical data collection, and the more broad macro-politics related to national political moods (Trump-era politics and feelings), disciplinary attitudes and ideologies (like dataism and post qualitative shininess), and embedded historical attitudes about the position of the researcher and the importance of "being there" in qualitative inquiry. I aimed to use a posthuman autoethonography to show that the researcher can be conceived of not as a singular subject but as a fulcrum or knot of material discursive and affective forces.

Importantly, I set out to highlight the jarring moments in the development of the research method. Following the notion that the researcher is an assemblage, I chose moments when I was jarred, and this jarring represented moments where, as the researcher, my sense of self was realigned with my core feminist material values. This realignment also forced the recalibration and redesign of my research method. In the first section, I show how I was affectively jarred by the testimonials of the DigitaLENS program. This jarring forced me to reflect on the way I thought about myself as a researcher-as a singular overworked female academic and mother. Turning to posthumanism became a way to rethink my subjectivity as an assemblage, allowing me to move beyond my seemingly singular concerns to recognize my personal privilege, my privilege within academia, and my responsibility to my participants.

The second jarring moment was a technological jarring. Confronted with a series of technological setbacks (glitchy apps, apps that only ran on expensive phones, limitations of data storage, and recording devices that made my participants feel uncomfortable), I again had to pause, sit with the trouble, and recognize that the method as I was mapping it out did not align 
with my feminist ethics of care. In rooting my conviction in my values and becoming more of a feminist material scholar, I made the choice to make a method that also adopted these values.

The third moment of jarring was the moment I realized that I had to forego the power of disciplinary logics to adhere to my feminist material response-abilities. I was inspired by a piece of scholarship that reminded me that sometimes the presence of the researcher in the moment of data gathering fundamentally influences the data. I realized that making my participants participant-researchers enabled a series of benefits that aligned with my feminist values: I communicated to my participants that I trusted them. I trained them as researchers, which gave them valuable skills that some of them used after the research to apply to graduate school. It also respected the typical method of self-imaging, as taking images of oneself is fundamentally a vulnerable and solitary act and should be respected as such. Redesigning the method after this final moment of jarring affirmed my values as a feminist materialist researcher and also shaped the method to align with those values. These three jarring moments therefore show moments where the method and methodologist intra-acted to become together.

In adopting a posthuman autoethnography, I'm permitted to draw on many forms of data not typically recognized as legitimate data in research. I toggle between emails, conference talks, personal conversations, diaries, my own reflections, and memories that are never just my own, but are entangled with other voices like those of research participants, as well as the neo-liberal institutional expectations of academia. I draw on these modalities to show how a posthuman autoethnography differs from a standard autoethnography: it gives voice to and traces material, discursive, and affective threads through what is deemed the author's voice while attempting to emphasize that this voice is implicitly decentered, multiple, nomadic, and tied to normative research responsibilities and modes of communication (e.g. conference talks and books), while also tied to our identities as teachers, and beyond this as just humans/non-humans entangled with our everyday lives, interests, and goals.

So to conclude, what this paper has offered the phematerial field of methodological praxis is two-fold: 1) I've aimed to provide a posthuman autoethnographic account of the mangle involved in the jarring encounters in the becoming of a research method, and 2) I've tried to show the various forces that come into play and with which we battle in the becoming of method(ologist) amidst the various scales of power within and outside academia. This type of work makes some of the invisible visible in the development of methods and also contributes to postqualitative research by reminding us that, of all the steps in the research inquiry, methods is the one presumed to be the least malleable. In fact (just kidding), methods, and creating, evolving, and introducing and adapting new methodologies, is what permits us to access new ways of knowing, because these methods are the tools we use to know and produce lively meaning. Importantly, this paper recognizes the embeddedness of values and principles in the 
design of methods and the production of academics as methodologists, something that is too often hidden and disguised. As such, without a rethinking of the ontological premises on which qualitative methods are founded, we will inevitably continue to know only that which our tools enable us to see and count as data, findings and research.

NYC, April 2018, AERA

Discussing introduction to PhEmaterialism in Education. Taylor and Francis 2018. Eds. Jessica Ringrose, Katie Warfield, Shiva Zarabadi. (All editors present)

Some salad bar in North Manhattan where you pick the vegetables and they chop them up in front of you. These salads were massive. I think it took me 3 hours to eat $1 \mathrm{lb}$ of kale covered in feta.

Jessica Ringrose: We have to have the Audre Lourde line in there somewhere: "For the masters tools will never dismantle the master's house. They may allow us temporarily to beat him at his own game, but they will never enable us to bring about genuine change." (Lorde, 1984, p.112)

Katie: I like that. It's sort of the key, isn't it? (pause). Do you think anyone ever finishes one of these salads?

\section{References}

Barad, K. (2007). Meeting the universe halfway. Durham: Duke University Press. https://doi.org/10.1215/9780822388128

Bennett, J. (2010). Vibrant matter: A political ecology of Things. Durham: Duke University Press. https://doi.org/10.1215/9780822391623

Braidotti, R. (2013). The posthuman. Cambridge: Polity Press.

Butz, D. \& Cook, N. (2017). The epistemological and ethical value of autophotography for mobilities research in transcultural contexts. Studies in Social Justice, 11(2), 238-274. https://doi.org/10.26522/ssj.v11i2.1629

Chau Vu, (2018) New materialist auto-ethico-ethnography: Agential-realist authenticity and objectivity in intimate scholarship. In K. Strom, T. Mills, \& A. Ovens (Eds.), Decentering the researcher in intimate scholarship: Critical posthuman methodological perspectives in education, 75-89. Bingley, UK: Emerald Publishing. https://doi.org/10.1108/S1479368720180000031007

Corson, J. \& Schwitzman, T. (2018) We, monsters: An autoethnographic literature review of experiences in doctoral education programs (kind of) In K. Strom, T. Mills, \& A. Ovens 
(Eds.), Decentering the researcher in intimate scholarship: critical posthuman methodological perspectives in education, 45.-58. Bingley, UK: Emerald Publishing. https://doi.org/10.1108/S1479-368720180000031005

Dikinson, S. (2018) Writing Sensation. In S. Holman Jones \& M. Pruyn (Eds.) Creative selves/creative cultures: Critical autoethnography, performance and pedagogy, 79-92. London: Palgrave. https://doi.org/10.1007/978-3-319-47527-1_5

Fox, N. (2016, June). Memory as Data. Crossroads Conference. Talk. Sydney, Australia.

Gale, K. \& Wyatt, J. (2018), Autoethnography and activism: Movement, intensity, and potential. Qualitative Inquiry, 25(6), 566-568. https://doi.org/10.1177/1077800418800754

Haggerty, K. and Erikson, R. (2003). The Surveillant Assemblage. The British Journal of Sociology, 1(4), 605-622.

Haraway, D. J. (2016). Staying with the trouble: Making kin in the Chthulucene. Durham: Duke University Press. https://doi.org/10.1215/9780822373780

Harris, A \& Jones, S. (2018). I am a monument. In S. Holman Jones \& M. Pruyn (Eds.) Creative selves/creative cultures. Critical autoethnography, performance and pedagogy, 113129. London: Palgrave. https://doi.org/10.1007/978-3-319-47527-1_8

Hook, G. A., \& Wolfe, M. J. (2018). Affective violence: Re/negotiating gendered-feminism within new materialism. Journal of Gender Studies, 27(8), 871-880.

Kuntz, A., \& Presnall, M. (2012). Wandering the tactical. Qualitative Inquiry, 18(9), 732-744. https://doi.org/10.1177/1077800412453016

Lather, P. (2018). Post critical methods. London: Taylor and Francis.

Lather, P. and St. Pierre, E.A. (2013). Post qualitative research. International Journal of Qualitative Studies in Education, 26(6), 629-633. https://doi.org/10.1080/09518398.2013.788752

Lather, P. (2016). Top 10 list: Rethinking ontology in post qualitative research. Cultural StudiesCritical Methodologies, 16(2), 125-131. https://doi.org/10.1177/1532708616634734

Latour, B., \& Woolgar, S. (1986). Laboratory life: The construction of scientific facts. Princeton, N.J: Princeton University Press. https://doi.org/10.1515/9781400820412

Lenz Taguchi, H. (2012). A diffractive and Deleuzian approach to analysing interview data. Feminist Theory, 13(3), 265-281. https://doi.org/10.1177/1464700112456001

Lorde, A. (2007). The master's tools will never dismantle the master's house. In A. Lorde (Ed.) Sister outsider: Essays and speeches (110-114). Berkley, CA: Crossing Press.

MacLure, M. (2013). Researching without representation? Language and materiality and post qualitative methodology. International Journal of Qualitative Studies in Education, 26(6), 658 -667. https://doi.org/10.1080/09518398.2013.788755

Mol, A. (2002). The body multiple: Ontology in medical practice. Durham: Duke University Press. https://doi.org/10.1215/9780822384151 
Pickering, A (1995,). The mangle of practice: Time, agency and science. Chicago: University of Chicago Press. https://doi.org/10.7208/chicago/9780226668253.001.0001

Raun, T. (2016). Out online: Trans self-representation and community building on Youtube. London: Routledge, Taylor \& Francis Group.

Renold, E. \& Ringrose, J. (2019). JARing: making phematerialist research practices matter", MAl: Feminist and Visual Culture, spring issue.

St. Pierre, E.A. (2014). A brief and personal history of post qualitative research: Toward "Post Inquiry". JCT (Online), 30(2), 1044-1064.

Strom, K., Mills, T., \& Ovens, A. Introduction: Decentering the researcher in intimate scholarship. In K. Strom, T. Mills, \& A. Ovens (Eds.), Decentering the researcher in intimate scholarship: critical posthuman methodological perspectives in education, 1-8. Bingley, UK: Emerald Publishing. https://doi.org/10.1108/S1479-368720180000031002

Taylor, C. (2017). Rethinking the empirical in higher education: Post qualitative inquiry as a less comfortable social science. International Journal of Research and Method in Education, 40(3), 311-326. https://doi.org/10.1080/1743727X.2016.1256984

Van Dijck, J. (2014). Datafication, dataism, and dataveillance: Big data between scientific paradigm and ideology. Surveillance and Society, 12(2), 197-208. https://doi.org/10.24908/ss.v12i2.4776

Wolfe, C. (2010). What is posthumanism? Minneapolis: University of Minnesota Press. Youngblood Jackson, A. (2013). Posthuman data analysis of mangling practices. International Journal of Qualitative Studies and Education, 26(6), 741-748. https://doi.org/10.1080/09518398.2013.788762 